\title{
Rancang Bangun Sistem Informasi Geografis Rekomendasi Cagar Budaya Menggunakan Metode Analytic Hierarchy Process
}

\author{
http://dx.doi.org/10.28932/jutisi.v6i2.2593 \\ Nicolas Evander Suhandi ${ }^{*_{1}}$, Kristoko Dwi Hartomo ${ }^{{ }^{* 2}}$, Penidas Fiodinggo Tanaem ${ }^{\# 3}$ \\ ${ }^{*}$ Jurusan Sistem Informasi, Universitas Kristen Satya Wacana \\ Jl. Diponegoro 52-60 Salatiga - Indonesia 50711 \\ ${ }^{1}$ nicolasevander@gmail.com \\ $2 \mathrm{kristoko@uksw}$. edu \\ ${ }^{3}$ penidas.fiodinggoduksw. edu
}

\begin{abstract}
Salatiga City is a town located in the province of Central Java. In this town, there can be found many cultural heritage buildings that were built in the mid-18th century to 1940. Potential visitors would increase easier if a geographic information system is built. Tourists who visit can access the website to select or search for cultural heritage that they want to visit, therefore the availability of a geographic information system that provides information and data on the location of cultural heritage in digital maps is needed. The system must also consider aspects of the cultural heritage rating, the price of admission, and the condition of the cultural heritage to provide recommendations on which cultural heritage to be visited. Therefore the geographic information system of cultural heritage recommendations uses the analytical hierarchy process (AHP) method which can calculate multicriteria, multi alternatives, and provides cultural heritage recommendations. This system combines geographic information system as a provider of cultural heritage information and AHP decision support system to assist tourists in choosing cultural heritage.
\end{abstract}

Keywords - Analytical hierarchy process; cultural heritage; decision support system; geographic information system; webbased mapping.

\section{Pendahuluan}

Kota Salatiga terletak di Provinsi Jawa Tengah dengan luas wilayah kurang lebih $56,78 \mathrm{~km}^{2}$. Predikat "Kota Pusaka" [1] menjadikan daya pikat bagi wisatawan yang bersambang ke Kota Salatiga. Selain itu di Kota Salatiga masih banyak ditemukan bangunan kuno yang dibangun sejak pertengahan abad ke 18 sampai tahun 1940. Potensi ini akan lebih dapat berdaya guna bila diintegrasikan dalam sebuah program wisata terpadu.

Keterbatasan informasi mengenai informasi cagar budaya, harga tiket masuk, popularitas dan pengenalan cagar budaya yang kurang menjadi masalah lain yang dihadapi bagi para wisatawan terutama yang baru pertama kali mengunjungi suatu tempat baru yang dalam hal ini Kota
Salatiga, maka dari itu Kota Salatiga memerlukan sarana pendukung berupa panduan tentang cagar budaya agar mempermudah wisatawan yang akan berkunjung. Informasi tentang cagar budaya ini memerlukan tersedianya sistem informasi yang akurat dan informatif, baik itu mengenai alamat cagar budaya, harga tiket masuk, kondisi cagar budaya dan informasi lainnya yang berkaitan dengan cagar budaya. Sistem informasi geografis cagar budaya dibuat untuk mempermudah pendistribusian informasi kepada para calon wisatawan [2].

Pencarian informasi cagar budaya dapat memanfaatkan teknologi informasi yang memudahkan pengguna dalam mengakses sebuah informasi. Penelitian ini menggunakan web-GIS dan sistem pendukung keputusan dalam penyediaan informasi. Web-GIS dapat memberikan informasi tata letak cagar budaya dalam bentuk peta digital sedangkan sistem pendukung keputusan digunakan oleh wisatawan dalam menentukan cagar budaya yang akan dikunjungi [3].

Dalam rekomendasi cagar budaya ini mempunyai multi kriteria dan multi alternatif, dikatakan memiliki multi kriteria dikarenakan melibatkan faktor popularitas, harga tiket masuk, dan kondisi cagar budaya. Berikutnya rekomendasi cagar budaya juga memiliki multi alternatif karena di Kota Salatiga terdapat beberapa cagar budaya. Sistem yang mendukung rekomendasi menggunakan multi kriteria dan multi alternatif inilah yang mendorong penelitian ini memakai metode Analytical Hierarchy Process (AHP) sebagai sistem pendukung keputusan, dalam metode AHP, semua kriteria di sistem rekomendasi cagar budaya akan disusun secara hierarki dan tingkat kepentingan tiap-tiap kriteria akan dihitung secara akurat [4]. Berdasarkan kondisi tersebut, maka penelitian ini berfokus pada pengarsipan data lokasi dan informasi mengenai cagar budaya di Kota Salatiga yang kemudian diolah ke sistem pendukung keputusan agar menghasilkan rekomendasi cagar budaya ke pengguna sistem. 
Tujuan penelitian ini dilaksanakan adalah untuk menghasilkan rancang bangun sistem informasi geografis rekomendasi cagar budaya di Salatiga.

Hasil dari penelitian ini juga diharapkan dapat mempermudah para pengguna dalam pencarian data dan informasi akan cagar budaya yang ada di Salatiga, serta dapat memudahkan para wisatawan dalam mengambil keputusan cagar budaya yang akan dikunjungi.

\section{Tinjauan PUSTAKa DAN Landasan TEORI}

Penelitian terdahulu yang menggabungkan sistem informasi dan metode AHP memanfaatkan sistem informasi dalam mengelola data supplier, barang, merk, penjualan, pembelian, pengaturan pengguna, pembeli, pengembalian pembelian, proses akuntansi serta memutuskan rekomendasi supplier dengan memakai metode AHP berdasarkan kriteria yang telah ditentukan [5]. Metode AHP juga digunakan pemilihan mobil bekas, kriteria yang terdiri dari dokumen, mesin, interior, eksterior dan tahun sebagai bahan pertimbangan untuk pelanggan agar dapat memaksimalkan efisiensi waktu dalam pengambil keputusan [6].

\section{A. Sistem Informasi Geografis}

Sistem Informasi Geografis adalah sistem yang dibuat untuk mengolah data koordinat lokasi atau data spasial. SIG mempunyai kapabilitas untuk mengolah data dan melaksanakan operasi-operasi dengan cara menampilkan dan menganalisis data. Pengembangan selanjutnya dari aplikasi SIG dikenal dengan web-GIS, yaitu aplikasi SIG yang berbasis web. SIG adalah gabungan dari perangkat lunak dan perangkat keras komputer data geografis serta manajemen yang dirancang untuk merubah, menyimpan, menganalisa dan memanipulasi semua bentuk informasi yang memiliki referensi geografis [7].

Sistem informasi geografis berdaya guna dalam menganalisis data spasial dan menyediakan informasi sehingga berdampak pada proses pengambilan keputusan [8].

Sedangkan bentuk dari sebuah data dalam SIG antara lain adalah:

- Data spasial, ialah bentuk data yang mewakili referensi geografis (georeference) dari suatu fenomena atau kondisi yang terdapat di dunia. Sumber data spasial dapat berasal dari peta analog, data hasil pengukuran lapangan, data penginderaan jarak jauh dan data global positioning system. Data spasial juga biasa disebut sebagai data keruangan, koordinat ataupun posisi.

- Data non spasial atau data non-atribut ialah bentuk data yang biasanya berupa tabel dan didalamnya berisi informasi-informasi dari entitas dalam data spasial. Sumber data non spasial dapat berasal dari data survei, data sensus ataupun data lain yang berbentuk angka.

\section{B. Cagar Budaya}

Cagar budaya memiliki arti: "Warisan budaya bersifat kebendaan berupa Benda Cagar Budaya, Bangunan Cagar Budaya, Struktur Cagar Budaya, Situs Cagar Budaya, dan Kawasan Cagar Budaya di darat dan/atau di air yang perlu dilestarikan keberadaannya karena memiliki nilai penting bagi sejarah, ilmu pengetahuan, pendidikan, agama, dan/atau kebudayaan melalui proses penetapan” sebagaimana ditulis di Undang-Undang Republik Indonesia No.11 Tahun 2010 Tentang Cagar Budaya,.

Syarat yang menjadikan sebuah bangunan dapat disebut cagar budaya menurut Undang-Undang Republik Indonesia No. 11 Tahun 2010 Tentang Cagar Budaya adalah jika memenuhi syarat antara lain:

- Mewakili gaya suatu masa paling singkat selama lima puluh tahun.

- Memiliki nilai budaya bagi penguatan kepribadian bangsa.

- Bangunan tersebut telah berusia paling tidak lima puluh tahun atau lebih.

- Memiliki arti khusus bagi ilmu pengetahuan, sejarah, , agama, kebudayaan dan/atau pendidikan.

\section{Diagram Use Case}

Diagram Use case adalah penjelasan suatu sistem dari perspektif pengguna sistem. Use case menunjukkan fungsifungsi dari suatu sistem yang dapat diakses oleh aktor [9]. Elemen yang membentuk sebuah use case terdiri dari use case itu sendiri, sistem dan aktor. Use case juga menjelaskan korelasi antara sistem informasi yang dirancang dengan satu atau lebih aktor. [10].

\section{Diagram Class}

Diagram class menjelaskan interaksi antar class dalam suatu sistem. Diagram Class berfungsi untuk mencitrakan kelas atau objek cetak biru dari sebuah sistem dan juga merupakan salah satu diagram utama dari Unified Modelling Language (UML). Penyusunan sebuah diagram class sangat mempengaruhi arsitektur suatu sistem, mulai dari perancangan perangkat lunak sampai tahap pemrograman [11].

\section{E. Analytical Hierarchy Process}

Analytical Hierarchy Process (AHP) merupakan sistem pendukung keputusan banyak kriteria yang digunakan dalam menyelesaikan masalah yang rumit ataupun kompleks. AHP membentuk kondisi yang tidak beraturan menjadi variabel-variabel kemudian menjadi hierarki yang efisien ataupun sistemis untuk menampilkan permasalahan. Hasil akhir dari AHP adalah melakukan perbandingan berpasangan berdasarkan pembobotan dari pengguna sehingga menghasilkan susunan prioritas untuk alternatif [4]. Bobot nilai dari tiap kriteria ataupun alternatif dihitung pada metode AHP ini, dengan memerhatikan prinsip dasar [12] dari AHP sebagai berikut: 
1) Membuat Hierarki: Dengan membagi elemenelemen pendukung kemudian membangun elemen sebagai hierarki, dan menyatukannya ataupun mensintesiskannya maka sekalipun sistem tersebut rumit maka dapat dipahami,

2) Melakukan pembobotan nilai kriteria dan alternatif: Pembobotan nilai kriteria dan alternatif dilaksanakan dengan cara perbandingan berpasangan. Berdasarkan Saaty, pembobotan nilai kriteria dan alternatif dilakukan menggunakan skala dari 1 sampai 9. Seperti yang ditunjukkan oleh Tabel I.

TABEL I

TABel Skala Pembobotan Nilai PERbandingan Berpasangan

\begin{tabular}{|c|l|}
\hline $\begin{array}{c}\text { Intensitas } \\
\text { Kepentingan }\end{array}$ & \multicolumn{1}{|c|}{ Keterangan } \\
\hline 1 & Kedua komponen sama pentingnya \\
\hline 3 & $\begin{array}{l}\text { Komponen yang satu sedikit lebih penting } \\
\text { daripada yang satunya }\end{array}$ \\
\hline 5 & $\begin{array}{l}\text { Komponen yang satu esensial daripada } \\
\text { komponen satunya }\end{array}$ \\
\hline 7 & $\begin{array}{l}\text { Satu komponen tersebut jelas lebih penting } \\
\text { dibanding komponen lainnya }\end{array}$ \\
\hline 9 & $\begin{array}{l}\text { Satu komponen absolut lebih penting } \\
\text { daripada komponen satunya. }\end{array}$ \\
\hline Kebalikan & $\begin{array}{l}\text { Nilai-nilai antara di antara dua penilaian yang } \\
\text { berdekatan }\end{array}$ \\
\hline $\begin{array}{l}\text { Semisal komponen i memperoleh satu angka } \\
\text { dibanding dengan komponen j, maka } \\
\text { komponen i mempunyai nilai kebalikannya } \\
\text { dibandingkan dengan nilai komponen j }\end{array}$ \\
\hline
\end{tabular}

Perbandingan pembobotan nilai yang ditunjukkan tabel I akan menciptakan bobot prioritas masing masing kriteria jika matriks perbandingan berpasangan diisi..

3) Konsistensi Logis: Adalah acuan dari pembobotan nilai perbandingan berpasangan yang dipakai dalam metode AHP dan juga indeks pendekatan matematis. Pembobotan nilai ini dilaksanakan pada atribut utama dari kerangka hierarki yang disusun, konsistensi dari pembobotan nilai dapat dinilai baik atau dapat diterima jika hasil yang didapat dari hasil pembobotan nilai berjumlah kurang dari sama dengan 0.1 dan dapat melanjutkan pembobotan pada langkah selanjutnya. Langkah-langkah dalam menghitung Consistency Ratio (CR) adalah [4]:

- Membentuk matriks perbandingan, yang diubah menjadi bentuk desimal.

- Matriks perbandingan tersebut dikalikan dengan matriks bobot prioritas

- Mencari nilai dari Maximum Eigen Value ( 2 max), seperti yang ditunjukkan pada rumus 1: $\lambda$ max $=\underline{\text { jumlah elemen pada matrik } y}$

- Mencari nilai perhitungan Consistency Index (CI) yang dapat dilihat pada rumus 2 :

$$
C I=\frac{(\lambda \max -n)}{(n-1)}
$$

- Mencari nilai dari perhitungan Consistency Ratio (CR) yang ditunjukkan pada rumus 3 :

$$
C R=\frac{C I}{I R}
$$

Nilai dari Index Random Consistency (IR) telah ditentukan oleh saaty [4] sebagaimana dapat dilihat pada Tabel II.

TABEL III

DAFTAR INDEX RANDOM CONSISTENCY (IR)

\begin{tabular}{|c|c|c|c|}
\hline $\begin{array}{c}\text { Ukuran } \\
\text { Matriks }\end{array}$ & $\begin{array}{c}\text { Nilai IR } \\
\text { (Incosistency) }\end{array}$ & $\begin{array}{c}\text { Ukuran } \\
\text { Matriks }\end{array}$ & $\begin{array}{c}\text { Nilai IR } \\
\text { (Incosistency) }\end{array}$ \\
\hline 1,2 & 0,00 & 9 & 1,45 \\
\hline 3 & 0,58 & 10 & 1,49 \\
\hline 4 & 0,90 & 11 & 1,51 \\
\hline 5 & 1,12 & 12 & 1,48 \\
\hline 6 & 1,24 & 13 & 1,56 \\
\hline 7 & 1,32 & 14 & 1,57 \\
\hline 8 & 1,41 & 15 & 1,59 \\
\hline
\end{tabular}

Jika hasil perhitungan $C R$ kurang lebih dari sama dengan 0.1 , perhitungan dapat dilanjutkan pada tahap selanjutnya, tetapi jika $C R$ lebih dari 0.1 , proses pembobotan nilai harus diulang kembali karena tidak konsisten.

\section{F. Pengujian Sistem (Blackbox Testing)}

Pengujian sistem pada SIG rekomendasi cagar budaya bertujuan untuk menemukan issue atau bug pada sistem agar dapat diperbaiki sebelum sistem atau aplikasi tersebut digunakan oleh pengguna. Pengujian pada SIG rekomendasi cagar budaya digunakan metode blackbox testing. Blackbox testing merupakan proses pengetesan akan sebuah aplikasi ataupun sistem tanpa memerhatikan kerangka algoritma pada software itu sendiri [13]. Fokus pada pengujian sistem menggunakan metode blackbox testing adalah berdasarkan dari fungsi dari sistem atau aplikasi tersebut dan juga keluaran atau output setelah melakukan fungsi dari suatu sistem atau aplikasi [14].

\section{METODE PENELITIAN}

Penelitian ini secara garis besar menggunakan sistem informasi geografis untuk media informasi dan metode AHP untuk proses pengambilan keputusan. Tahap penelitian ini dimulai dari pendefinisian tujuan, manfaat dan batasan masalah sistem untuk memutuskan menggunakan kriteria apa saja dalam mencari rekomendasi cagar budaya. Studi literatur penunjang sehingga mendapatkan metode yang digunakan yaitu AHP. Pemodelan sistem dalam bentuk hierarki sistem, diagram use case, diagram class, pemrograman sistem, pengujian sistem dan pembuatan laporan akhir. Tahap penelitian dari rancang bangun sistem informasi geografis dapat dilihat pada gambar 1 . 


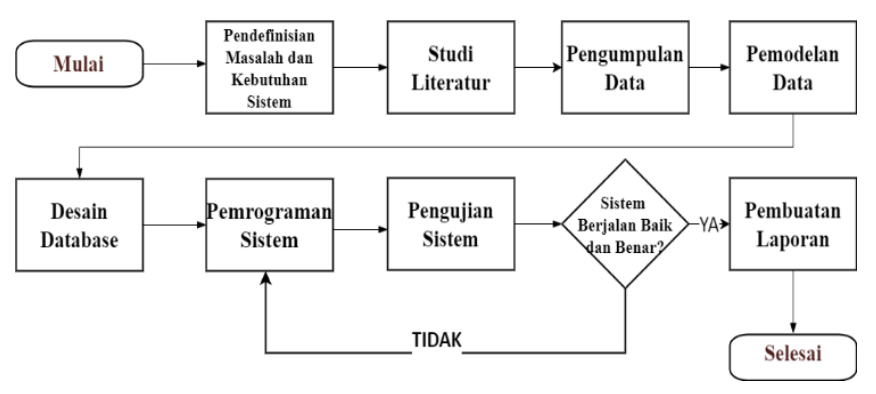

Gambar 1. Tahap Penelitian

\section{G. Gambaran Umum Sistem}

Sistem informasi rekomendasi cagar budaya menggunakan metode AHP dirancang berbasis web. Menu utama yang terdapat pada sistem informasi rekomendasi cagar budaya adalah menu pencarian cagar budaya dan pencarian rekomendasi cagar budaya. Pengguna yang ingin mencari informasi cagar budaya dapat menginputkan nama cagar budaya yang diinginkan pada kolom search maka akan ditampilkan marker cagar budaya pada peta beserta informasi cagar budaya tersebut. Pengguna yang ingin mencari rekomendasi cagar budaya harus mengisi form yang berisi beberapa kriteria yaitu rating, harga tiket masuk dan kondisi. Hasil data yang dimasukkan oleh pengguna akan diproses dengan memakai metode AHP yang akan menghasilkan rekomendasi cagar budaya. Gambaran umum sistem informasi geografis rekomendasi cagar budaya ditunjukkan pada gambar 2.

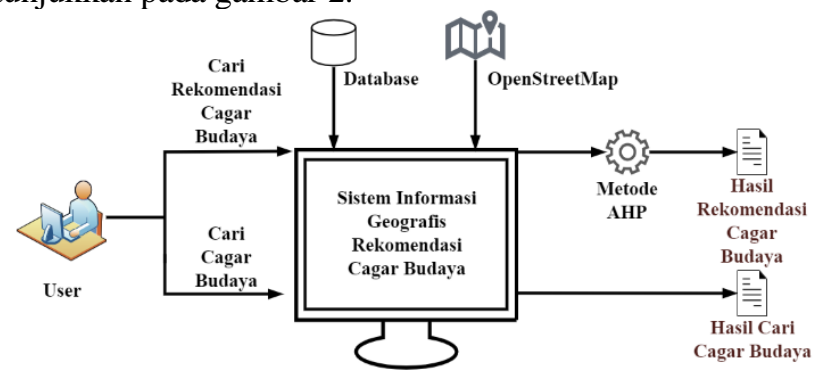

Gambar 2. Gambaran Umum Sistem

\section{H. Pengumpulan Data}

Sumber data yang diproses pada penelitian ini menggunakan data primer dan data sekunder:

1) Data Primer: Data primer SIG rekomendasi cagar budaya didapat melalui wawancara dengan Kepala Seksi Sejarah, Cagar Budaya dan Permuseuman di Dinas Kebudayaan dan Pariwisata Kota Salatiga dan juga observasi ke cagar budaya yang berada di Kota Salatiga. Wawancara dan observasi ini dilaksanakan agar mengetahui apa saja cagar budaya yang berada di Kota Salatiga.

2) Data Sekunder: Data sekunder SIG rekomendasi cagar budaya didapat melalui pencarian ke berbagai sumber tulisan yang relevan mengenai cagar budaya dan melakukan pencatatan daftar cagar budaya yang ada di situs sistem registrasi nasional cagar budaya milik Kementerian Pendidikan dan Kebudayaan Republik Indonesia [15]. Dari keseluruhan data, diputuskan untuk memakai kategori bangunan cagar budaya. Dari kategori tersebut, didapatkan sebanyak 6 data cagar budaya.

\section{Pemodelan Data}

Data yang didapat dari pengumpulan data kemudian dianalisis menggunakan metode Analytic Hierarchy Process (AHP):

1) Pemodelan data pada kriteria dan alternatif: Ada tiga kriteria yang digunakan SIG rekomendasi cagar budaya sebagai penilaian rekomendasi cagar budaya yaitu:

$\mathrm{K} 01=$ Rating

K02 = Harga Tiket Masuk

K03 = Kondisi Cagar Budaya

Ada enam alternatif yang digunakan menjadi sampel rekomendasi cagar budaya yaitu:

A01 $=$ Kompleks Rumah Dinas Walikota Salatiga

A02 $=$ Hotel Mutiara

A03 $=$ Kantor Walikota Salatiga

A04 = Rumah Tinggal / Bekas Tanah Gedung Pakuwon

$\mathrm{A} 05=\mathrm{GPIB}$

A06 $=$ Abyss House

2) Penjelasan tentang tiga kriteria tersebut adalah:

- Rating: Rating atau nilai skor didapat dari ulasan dari pengunjung yang pernah berkunjung sebelumnya ke cagar budaya tersebut.

- Harga Tiket Masuk: Semakin murah harga tiket masuk maka nilai yang dihasilkan maka akan lebih tinggi

- Kondisi: Kondisi cagar budaya dinilai dari terawatnya cagar budaya tersebut.

\section{J. Diagram Use Case}

Diagram use case mewakili hubungan sebuah sistem dengan aktor. Rancangan diagram use case untuk SIG rekomendasi cagar budaya dibuat berdasarkan identifikasi kebutuhan yang sebelumnya telah didefinisikan.

Penjelasan dari diagram use case pada gambar 3 adalah sebagai berikut:

1) Pengguna: Pengguna dapat melakukan proses pencarian cagar budaya menggunakan peta yang sudah tersedia di bagian beranda SIG Rekomendasi Cagar Budaya dan dapat juga melakukan pencarian yang lebih spesifik menggunakan menu daftar cagar budaya. Setelah itu pengguna dapat melakukan penentuan prioritas terhadap rating, harga tiket masuk, dan kondisi cagar budaya di menu hitung AHP.

2) Admin: Admin dapat menjalankan semua akses dan fungsi dari SIG rekomendasi cagar budaya. Admin dapat menjalankan proses pencarian cagar budaya baik di 
beranda maupun di menu daftar cagar budaya, melakukan penentuan prioritas terhadap rating, harga tiket masuk dan kondisi cagar budaya di menu hitung AHP, melakukan penambahan data cagar budaya, melakukan perubahan pada data cagar budaya, melakukan penghapusan pada data cagar budaya, melakukan penambahan data kriteria AHP, melakukan perubahan data kriteria AHP dan melakukan penghapusan data kriteria AHP.

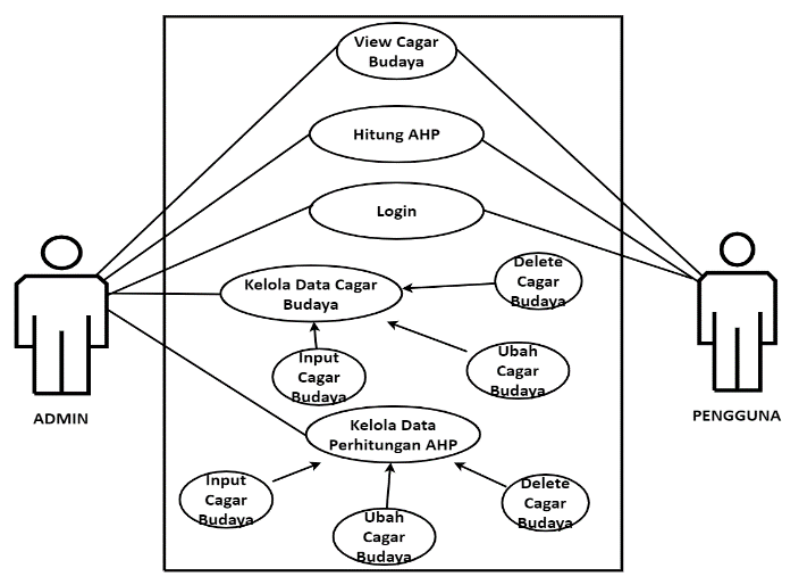

Gambar 3. Diagram Use Case

\section{K. Diagram Class}

Berdasarkan rancangan diagram use case SIG rekomendasi cagar budaya, maka dapat dilakukan tahap selanjutnya yaitu perancangan struktur diagram class yang digunakan untuk menunjukkan hubungan antar tabel yang berada di SIG rekomendasi cagar budaya. Hubungan antar tabel dapat dilihat pada Gambar 4.

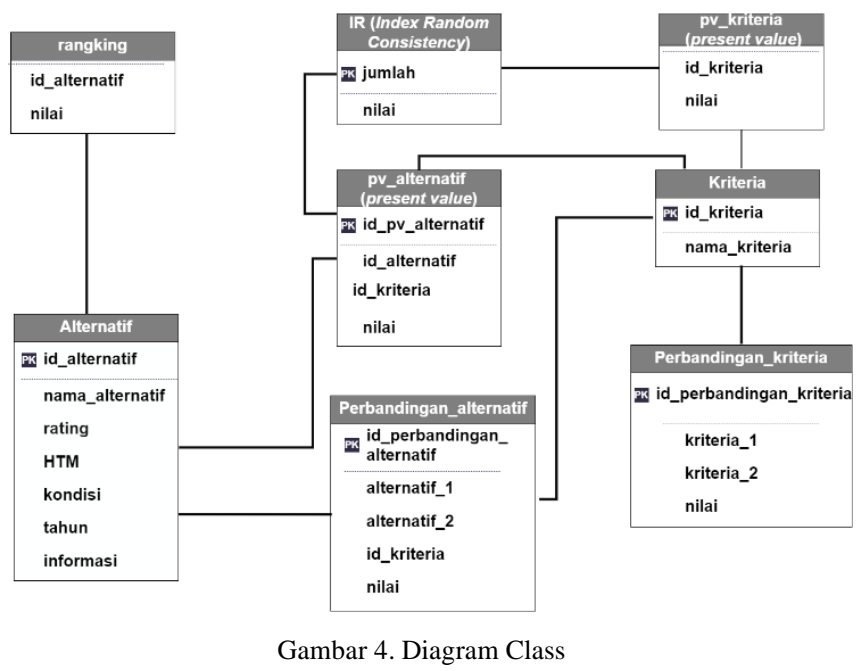

\section{IV.Pembahasan DAN PENGUJian}

\section{A. Studi Kasus Rekomendasi Cagar Budaya}

Dilakukan studi kasus terhadap rekomendasi cagar budaya agar dapat melihat contoh perhitungan dari metode analytical hierarchy process (AHP).

Pengguna awalnya akan diminta untuk mengisi pembobotan kriteria dengan cara melakukan pembobotan nilai pada matriks perbandingan berpasangan dengan cara membandingkan kriteria satu dengan yang lainnya berdasarkan prioritas. Hasil perbandingan berpasangan untuk matriks kriteria pada pemilihan cagar budaya ditunjukkan pada Tabel III.

\section{TABEL IIIII}

TABEL PERBANDINGAN BERPASANGAN KRITERIA

\begin{tabular}{|c|c|c|c|}
\hline Kriteria & K01 & K02 & K03 \\
\hline K01 & 1 & 5 & 3 \\
\hline K02 & 0,2 & 1 & 0,33 \\
\hline K03 & 0,33 & 3 & 1 \\
\hline Jumlah & 1,53 & 9 & 4,33 \\
\hline
\end{tabular}

Dilakukan normalisasi dengan cara membagi pembobotan nilai kriteria pada kolom pertama baris pertama dengan total jumlah perhitungan pada kolom pertama, kemudian membagi pembobotan nilai kriteria pada kolom kedua baris pertama dengan total jumlah perhitungan pada kolom kedua, dan selanjutnya setelah melakukan pembobotan nilai pada Tabel III. Hasil dari normalisasi Tabel III dapat dilihat pada Tabel IV.

TABEL IVV

TABEL HASIL NORMALISASI KRITERIA

\begin{tabular}{|c|c|c|c|}
\hline Kriteria & K01 & K02 & K03 \\
\hline K01 & 0,65217 & 0,55556 & 0,69231 \\
\hline K02 & 0,13043 & 0,11111 & 0,07692 \\
\hline K03 & 0,21739 & 0,33333 & 0,23077 \\
\hline
\end{tabular}

Langkah selanjutnya setelah melakukan normalisasi adalah mencari bobot prioritas atau priority vector. Kolom total of rows merupakan jumlah nilai tiap baris di Tabel IV. Sedangkan priority vector didapat dengan membagi total of rows dengan jumlah kolom yang ada pada Tabel IV. Hasil dari priority vector kriteria ditunjukkan pada Tabel V.

TABEL V

TABEL PRIORITY VECTOR KRITERIA

\begin{tabular}{|c|c|c|}
\hline Kriteria & Total of Rows & Priority Vector \\
\hline K01 & 1,9 & 0.6333 \\
\hline K02 & 0,31 & 0,1061 \\
\hline K03 & 0,78 & 0,2605 \\
\hline
\end{tabular}

Langkah selanjutnya setelah mendapatkan nilai priority vector kriteria pada Tabel $\mathrm{V}$ ialah menentukan konsistensi untuk matriks perbandingan kriteria:

- Hitung Principe Eigen Vector ( $\lambda$ max)

$\lambda \max =(0,63 \times 1,53)+(0,106 \times 0,33)+(0,26 \times 4,33)$

$$
=3,05536
$$

- Hitung Consistency Index (CI)

$$
C I \quad=\frac{(\lambda m a k s-n)}{(n-1)}=\frac{(3,05536-3)}{(3-1)}=0,02768
$$


- Hitung Consistency Ration (CR)

$$
C R=\frac{C I}{I R}=\frac{0,02768}{0,58}=0,477
$$

Setelah mendapat nilai pembobotan kriteria, Langkah selanjutnya adalah melakukan perhitungan pembobotan alternatif di setiap kriteria.

1) Perbandingan Berpasangan Alternatif Kriteria Rating: Tabel VI merupakan hasil perbandingan berpasangan untuk matriks alternatif kriteria rating. Tabel matriks perbandingan berpasangan alternatif kriteria rating ditunjukkan pada Tabel VI.

TABEL VI

TABEL MATRIKS ALTERNATIF KRITERIA RATING

\begin{tabular}{|c|c|c|c|c|c|c|}
\hline Alternatif & A01 & A02 & A03 & A04 & A05 & A06 \\
\hline A01 & 1 & 4 & 2 & 4 & 1 & 2 \\
\hline A02 & 0,25 & 1 & 0,2 & 0,5 & 0,2 & 0,25 \\
\hline A03 & 0,5 & 5 & 1 & 3 & 0,25 & 1 \\
\hline A04 & 0,25 & 2 & 0,33 & 1 & 0,25 & 0,33 \\
\hline A05 & 1 & 5 & 4 & 4 & 1 & 3 \\
\hline A06 & 0,5 & 4 & 1 & 3 & 0,33 & 1 \\
\hline Jumlah & 3,5 & 21 & 8,53 & 15,5 & 3,03 & 7,58 \\
\hline
\end{tabular}

Dilakukan normalisasi perbandingan berpasangan alternatif kriteria rating setelah melakukan perbandingan berpasangan pada Tabel VI. Dengan cara membagi pembobotan nilai kriteria pada kolom pertama baris pertama dengan total jumlah perhitungan pada kolom pertama, kemudian membagi pembobotan nilai kriteria pada kolom kedua baris pertama dengan total jumlah perhitungan pada kolom kedua, dan selanjutnya. Hasil dari normalisasi Tabel VI dapat dilihat pada Tabel VII.

TABEL VII

TABEL HASIL NORMALISASI ALTERNATIF KRITERIA RATING

\begin{tabular}{|c|c|c|c|c|c|c|}
\hline Alternatif & A01 & $\mathbf{A 0 2}$ & $\mathbf{A 0 3}$ & $\mathbf{A 0 4}$ & $\mathbf{A 0 5}$ & $\mathbf{A 0 6}$ \\
\hline A01 & 0,28 & 0,19 & 0,23 & 0,25 & 0,32 & 0,26 \\
\hline A02 & 0,07 & 0,04 & 0,02 & 0,03 & 0,06 & 0,03 \\
\hline A03 & 0,14 & 0,23 & 0,11 & 0,19 & 0,08 & 0,13 \\
\hline A04 & 0,07 & 0,09 & 0,03 & 0,06 & 0,08 & 0,04 \\
\hline A05 & 0,28 & 0,23 & 0,46 & 0,25 & 0,32 & 0,39 \\
\hline A06 & 0,14 & 0,19 & 0,11 & 0,19 & 0,10 & 0,13 \\
\hline
\end{tabular}

Tabel VIII adalah hasil dari matriks priority vector dan konsistensi logis alternatif untuk kriteria rating, untuk perhitungan. Dalam mencari principe eigen vector memakai rumus nomor 1, untuk consistency index memakai rumus nomor 2 dan consistency ration memakai rumus nomor 3 . Sedangkan GPIB merupakan alternatif dengan priority vector tertinggi dengan jumlah bobot 0,32 .

TABEL VIII

TABEL MATRIKS EIGEN VECTOR KRITERIA RATING

\begin{tabular}{|c|c|c|}
\hline Alternatif & Total of Rows & Priority Vector \\
\hline A01 & 1.56 & 0,2603 \\
\hline A02 & 0.27 & 0,0456 \\
\hline A03 & 0.905 & 0,151 \\
\hline
\end{tabular}

\begin{tabular}{|c|c|c|}
\hline $\mathrm{A} 04$ & 0.39 & 0,066 \\
\hline $\mathrm{A} 05$ & 1.97 & 0,3293 \\
\hline $\mathrm{A} 06$ & 0.88 & 0.1476 \\
\hline \multicolumn{2}{|l|}{ Principe Eigen Vector $(\lambda \mathrm{max})$} & 6,3 \\
\hline \multicolumn{2}{|c|}{ Consistency Index $(\mathrm{CI})$} & 0,061 \\
\hline Consistency Ration $(\mathrm{CR})$ & 0,0485 \\
\hline
\end{tabular}

Matriks perbandingan berpasangan kriteria rating dikatakan konsisten dikarenakan Consistency Ratio yang tidak mencapai angka 0,1 yaitu 0,0485.

2) Perbandingan Berpasangan Alternatif Kriteria Harga Tiket Masuk: Tabel IX adalah tabel matriks kriteria harga tiket masuk yang belum dinormalisasikan.

TABEL IX

TABEL MATRIKS AlterNATIF KRITERIA HARGA TIKET MASUK

\begin{tabular}{|c|c|c|c|c|c|c|}
\hline Alternatif & A01 & A02 & A03 & A04 & A05 & A06 \\
\hline A01 & 1 & 1 & 1 & 3 & 1 & 3 \\
\hline A02 & 1 & 1 & 1 & 3 & 1 & 3 \\
\hline A03 & 1 & 1 & 1 & 3 & 1 & 3 \\
\hline A04 & 0,33 & 0,33 & 0,33 & 1 & 0,33 & 1 \\
\hline A05 & 1 & 1 & 1 & 3 & 1 & 3 \\
\hline A06 & 0,33 & 0,33 & 0,33 & 1 & 0,33 & 1 \\
\hline Jumlah & 4.66 & 4.66 & 4.66 & 14 & 4.66 & 14 \\
\hline
\end{tabular}

Normalisasi perbandingan berpasangan dilakukan setelah melakukan perbandingan berpasangan pada Tabel IX, Dengan cara membagi pembobotan nilai kriteria pada kolom pertama baris pertama dengan total jumlah perhitungan pada kolom pertama, kemudian membagi pembobotan nilai kriteria pada kolom kedua baris pertama dengan total jumlah perhitungan pada kolom kedua, dan selanjutnya. Hasil dari normalisasi Tabel IX dapat dilihat pada Tabel X.

TABEL $X$

TABEl HASIL Normalisasi ALTERNATIF KRITERIA HARga TIKET MasuK

\begin{tabular}{|c|c|c|c|c|c|c|}
\hline Alternatif & A01 & A02 & A03 & A04 & A05 & A06 \\
\hline A01 & 0,21 & 0,21 & 0,21 & 0,21 & 0,21 & 0,21 \\
\hline A02 & 0,21 & 0,21 & 0,21 & 0,21 & 0,21 & 0,21 \\
\hline A03 & 0,21 & 0,21 & 0,21 & 0,21 & 0,21 & 0,21 \\
\hline A04 & 0,07 & 0,07 & 0,07 & 0,07 & 0,07 & 0,07 \\
\hline A05 & 0,21 & 0,21 & 0,21 & 0,21 & 0,21 & 0,21 \\
\hline A06 & 0,07 & 0,07 & 0,07 & 0,07 & 0,07 & 0,07 \\
\hline
\end{tabular}

Setelah melakukan normalisasi pada Tabel X, langkah selanjutnya adalah menentukan konsistensi dari perbandingan berpasangan alternatif kriteria harga tiket masuk. Dalam menghitung principe eigen vector memakai rumus nomor 1, untuk consistency index memakai rumus nomor 2 dan consistency ratio memakai rumus nomor 3. Sedangkan Kompleks Rumah Dinas Walikota Salatiga, Hotel Mutiara, Kantor Walikota Salatiga dan GPIB merupakan alternatif dengan Priority Vector tertinggi dengan jumlah bobot 0,214 dan Rumah Tinggal Gedung Pakuwon dan Abyss House merupakan alternatif dengan priority vector terendah dengan jumlah bobot 0,071 . 
TABEL XI

TABEl MAtriks Eigen Vector Kriteria HaRga TiKet MASUK

\begin{tabular}{|c|c|c|}
\hline Alternatif & Total of Rows & Priority Vector \\
\hline A01 & 1,28 & 0,2142 \\
\hline A02 & 1,28 & 0,2142 \\
\hline A03 & 1,28 & 0,2142 \\
\hline A04 & 0,42 & 0,0714 \\
\hline A05 & 1,28 & 0,2142 \\
\hline A06 & 0,42 & 0,0714 \\
\hline Principe Eigen Vector $(\lambda \max )$ & 6 \\
\hline Consistency Index $(C I)$ & 0 \\
\hline Consistency Ration $(C R)$ & 0 \\
\hline
\end{tabular}

Matriks perbandingan berpasangan kriteria rating dikatakan konsisten dikarenakan consistency ratio yang tidak mencapai angka 0,1 .

3) Perbandingan Berpasangan Alternatif Kriteria Kondisi: Tabel XII merupakan hasil perbandingan berpasangan untuk matriks alternatif kriteria kondisi.

TABEL XII

TABEL MATRIKS KRITERIA KONDISI

\begin{tabular}{|c|c|c|c|c|c|c|}
\hline Alternatif & A01 & A02 & A03 & A04 & A05 & A06 \\
\hline A01 & 1 & 5 & 1 & 5 & 2 & 5 \\
\hline A02 & 0.2 & 1 & 0.2 & 3 & 0.33 & 0.5 \\
\hline A03 & 1 & 5 & 1 & 5 & 3 & 3 \\
\hline A04 & 0,2 & 0,33 & 0,2 & 1 & 0,33 & 0,33 \\
\hline A05 & 0,5 & 3 & 0,33 & 3 & 1 & 2 \\
\hline A06 & 0,2 & 2 & 0,33 & 3 & 0,5 & 1 \\
\hline Jumlah & 3,1 & 16,3 & 3,66 & 20 & 7,16 & 11,83 \\
\hline
\end{tabular}

Tabel XIII menunjukkan hasil normalisasi dari Tabel XII, dengan cara membagi pembobotan nilai kriteria pada kolom pertama baris pertama dengan total jumlah perhitungan pada kolom pertama, kemudian membagi pembobotan nilai kriteria pada kolom kedua baris pertama dengan total jumlah perhitungan pada kolom kedua, dan selanjutnya. Hasil dari normalisasi dapat dilihat pada Tabel XIII.

TABEL XIII

TABEL HASIL NORMALISASI ALTERNATIF KRITERIA KONDISI

\begin{tabular}{|c|c|c|c|c|c|c|}
\hline Alternatif & A01 & A02 & A03 & A04 & A05 & A06 \\
\hline A01 & 0,32 & 0,306 & 0,32 & 0,25 & 0,27 & 0,42 \\
\hline A02 & 0,06 & 0,06 & 0,06 & 0,15 & 0,04 & 0,04 \\
\hline A03 & 0,32 & 0,306 & 0,32 & 0,25 & 0,41 & 0,25 \\
\hline A04 & 0,06 & 0,002 & 0,06 & 0,05 & 0,04 & 0,02 \\
\hline A05 & 0,16 & 0,18 & 0,108 & 0,15 & 0,13 & 0,16 \\
\hline A06 & 0,06 & 0,12 & 0,108 & 0,15 & 0,06 & 0,08 \\
\hline
\end{tabular}

Tabel XIV adalah hasil dari matriks eigen vector kriteria harga tiket masuk, untuk perhitungan Principe Eigen Vector memakai rumus nomor 1 , untuk consistency index memakai rumus nomor 2 dan consistency ratio memakai rumus nomor 3. Matriks perbandingan berpasangan alternatif untuk kriteria kondisi dikatakan konsisten dikarenakan consistency ratio yang tidak mencapai angka 1 yaitu 0,489. Kompleks Rumah Dinas Walikota Salatiga memiliki priority vector tertinggi dengan jumlah 0,3177 .
TABEL XIV

TABEl MATRIKS EIGEN VECTOR KRITERIA HARGA TIKET MASUK

\begin{tabular}{|c|c|c|}
\hline Alternatif & Total of Rows & Priority Vector \\
\hline A01 & 1,906 & 0,3177 \\
\hline A02 & 0,429 & 0,0716 \\
\hline A03 & 1,876 & 0,3128 \\
\hline A04 & 0,274 & 0,0458 \\
\hline A05 & 0,912 & 0,152 \\
\hline A06 & 0,599 & 0,0999 \\
\hline Principe Eigen Vector $(\lambda \max )$ & 6,3029 \\
\hline \multicolumn{2}{|c|}{ Consistency Index $($ CI $)$} & 0,0605 \\
\hline Consistency Ration $(C R)$ & 0,489 \\
\hline
\end{tabular}

4) Nilai Total dan Pemeringkatan: Untuk mencari nilai total dengan mengalikan matriks alternatif tiap kriteria dengan matriks kriteria. Untuk nilai dari matriks tersebut dapat dilihat pada Tabel V, Tabel VIII, Tabel XI dan Tabel XIV.

$\left.\begin{array}{lccc} & \mathrm{K} 01 & \mathrm{~K} 02 & \underline{\mathrm{K} 03} \\ A 01 & 0,2603 & 0,2142 & 0,3177 \\ A 02 & 0,0456 & 0,2142 & 0,0716 \\ A 03 & 0,1510 & 0,2142 & 0,3128 \\ A 04 & 0,0661 & 0,0714 & 0,0458 \\ A 05 & 0,3293 & 0,2142 & 0,1520 \\ A 06 & 0,1476 & 0,0714 & 0,0999\end{array}\right) \times K 01\left(\begin{array}{l}0,6333 \\ 0,1061 \\ 0,2605\end{array}\right)$

Gambar 5. Perkalian Matriks Untuk Mendapat Nilai Akhir

Tabel nilai akhir dari perkalian matriks pada gambar 5 ditunjukkan di Tabel XV.

TABEL XV

TABEL NILAI AKHIR

\begin{tabular}{|c|c|c|}
\hline Alternatif & Nama Tempat & Nilai Akhir \\
\hline A01 & $\begin{array}{c}\text { Kompleks Rumah Dinas } \\
\text { Walikota Salatiga }\end{array}$ & 0.2704 \\
\hline A02 & Hotel Mutiara & 0,0702 \\
\hline A03 & Kantor Walikota Salatiga & 0,1998 \\
\hline A04 & $\begin{array}{r}\text { Rumah Tinggal / Bekas Tanah } \\
\text { Gedung Pakuwon }\end{array}$ & 0,0613 \\
\hline A05 & GPIB & 0,2709 \\
\hline A06 & Abyss House & 0,1271 \\
\hline
\end{tabular}

Tabel XVI adalah hasil pemeringkatan cagar budaya.Pada urutan pertama yang menunjukkan alternatif yang paling tinggi adalah GPIB dengan nilai 0,2709, kedua adalah Kompleks Rumah Dinas Walikota Salatiga dengan nilai 0,2704, ketiga adalah Kantor Walikota Salatiga dengan nilai 0,1998, keempat adalah Abyss House dengan nilai 0,1271, kelima adalah Hotel Mutiara dengan bobot 0,0702, kemudian terakhir adalah Rumah Tinggal Gedung Pakuwon dengan nilai 0,0613 . 
TABEL XVI

TABEL PEMERINGKATAN

\begin{tabular}{|c|c|c|}
\hline Peringkat & Nama Tempat & Nilai Akhir \\
\hline 1 & GPIB & 0,2709 \\
\hline 2 & $\begin{array}{c}\text { Kompleks Rumah Dinas } \\
\text { Walikota Salatiga }\end{array}$ & 0.2704 \\
\hline 3 & Kantor Walikota Salatiga & 0,1998 \\
\hline 4 & Abyss House & 0,1271 \\
\hline 5 & Hotel Mutiara & 0,0702 \\
\hline 6 & $\begin{array}{c}\text { Rumah Tinggal / Bekas Tanah } \\
\text { Gedung Pakuwon }\end{array}$ & 0,0613 \\
\hline
\end{tabular}

\section{B. Implementasi}

Tahap selanjutnya setelah melakukan studi kasus AHP, adalah implementasi sistem informasi geografis rekomendasi cagar budaya. Untuk data pembobotan nilai yang dipakai pada menu hitung AHP akan dipakai nilai dari studi kasus sebelumnya.

1) Form Halaman Utama: Pengguna akan dibawa ke halaman utama jika telah berhasil melakukan login. Pada tampilan antarmuka halaman utama terdapat sidebar yang berisi menu-menu yang terdapat di SIG rekomendasi cagar budaya, menu-menu tersebut adalah : menu utama, daftar cagar budaya dan hitung AHP yang terbagi menjadi 7 sub-menu yaitu: kriteria, alternatif, perbandingan kriteria, perbandingan rating, perbandingan harga tiket masuk, perbandingan kondisi dan hasil. Kemudian terdapat search box di halaman utama yang digunakan untuk mencari cagar budaya berdasarkan nama cagar budaya. Dibawah kolom search box terdapat peta Kota Salatiga dan marker yang menunjukkan lokasi cagar budaya, serta tabel yang menunjukkan informasi mengenai cagar budaya yang berisi alamat, tahun, kondisi dan informasi mengenai cagar budaya tersebut. Tampilan antarmuka SIG rekomendasi cagar budaya ditunjukkan pada gambar 6.

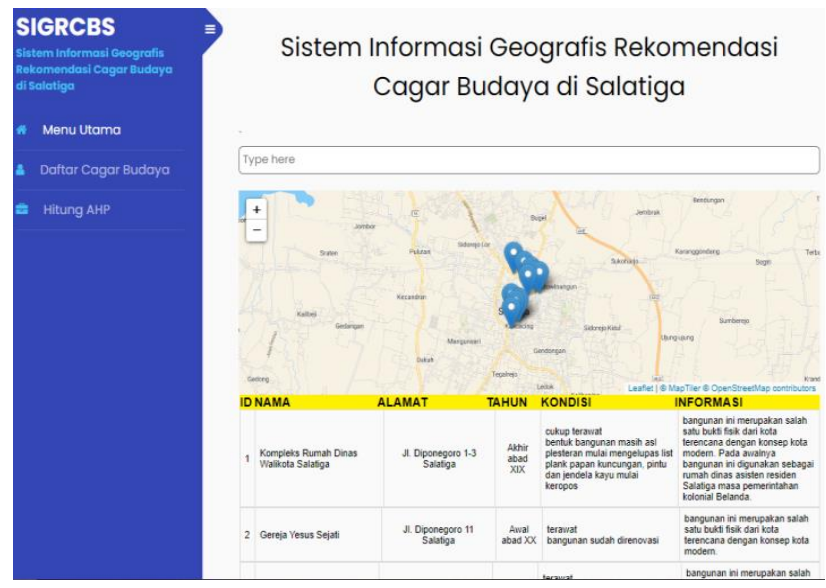

Gambar 6. Halaman Utama
2) Form Daftar Cagar Budaya: Menu daftar cagar budaya menampilkan informasi mengenai cagar budaya yang ada di Salatiga dan juga menampilkan gambar dari cagar budaya. User dapat melakukan penulusuran terhadap cagar budaya yang ada di Kota Salatiga. Tampilan antarmuka halaman daftar cagar budaya pada sistem informasi geografis rekomendasi cagar budaya di Salatiga dapat dilihat pada gambar 7 .
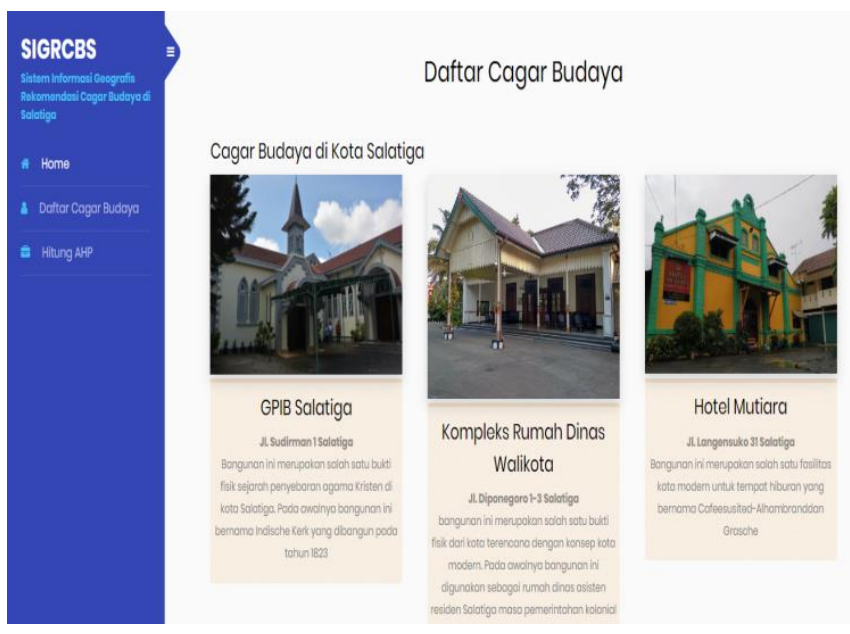

Gambar 7. Halaman Daftar Cagar Budaya

3) Form Kriteria: Fungsi halaman kriteria adalah untuk mengelola data kriteria. Form ini dapat digunakan oleh admin untuk mengelola data kriteria SIG rekomendasi cagar budaya dengan menggunakan button tambah untuk menambah data kriteria, update untuk mengubah data kriteria dan delete untuk menghapus data kriteria. Setelah admin melakukan perubahan pada data kriteria, maka perubaahn tersebut akan muncul pada menu perbandingan kriteria. Tampilan antarmuka dari menu kriteria dapat ditunjukkan gambar 8 .

\section{Kriteria}

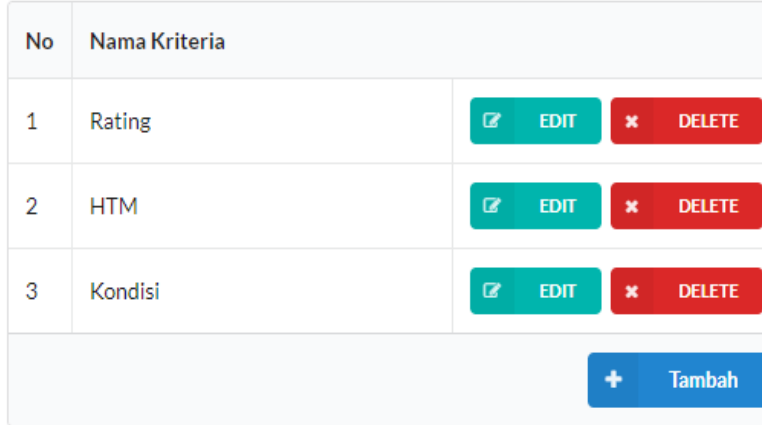

Gambar 8. Halaman Kriteria

4) Form Alternatif: Fungsi dari menu alternatif adalah untuk mengelola data alternatif. Admin dapat mengelola data alternatif SIG rekomendasi cagar budaya dengan menggunakan button yang tersedia pada menu alternatif, yaitu: tambah untuk menambah data alternatif, update 
untuk mengubah data alternatif dan delete untuk menghapus data alternatif. Setelah Admin melakukan perubahan pada menu alternatif, maka perubahan pada menu alternatif akan muncul pada menu perbandingan alternatif. Tampilan antarmuka menu alternatif ditunjukkan oleh gambar 9.

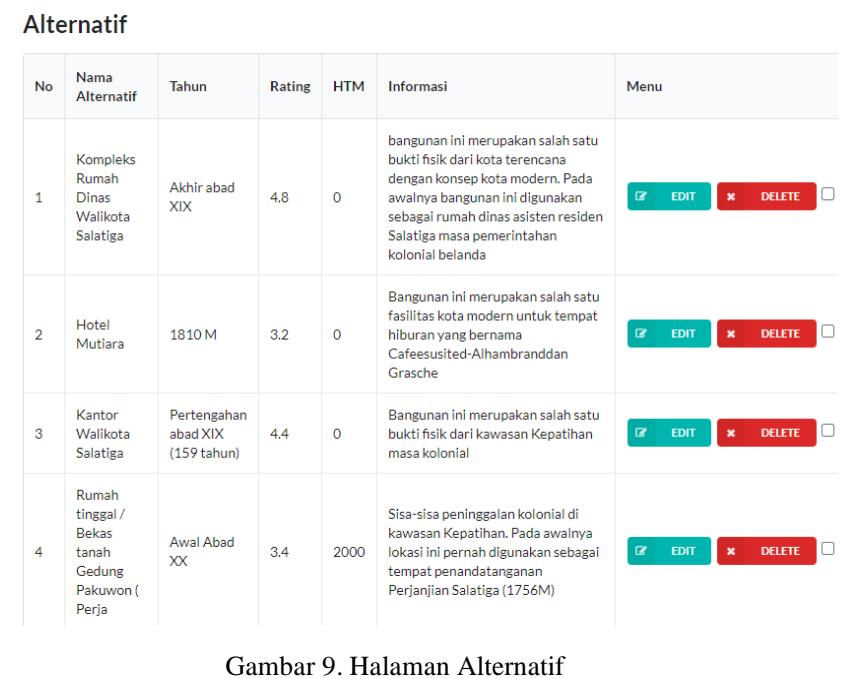

5) Form Perbandingan Kriteria: Halaman perbandingan kriteria digunakan oleh pengguna dalam melakukan pembobotan nilai perbandingan berpasangan untuk kategori kriteria dengan berpedoman pada tabel Saaty. Pengguna melakukan perbandingan kriteria satu dan lainnya pada halaman ini, setelah pembobotan nilai selesai, maka pengguna dapat menekan tombol submit untuk melanjutkan ke tahap selanjutnya. Tampilan antarmuka halaman perbandingan kriteria dapat ditunjukkan gambar 10.

\section{Perbandingan Kriteria}

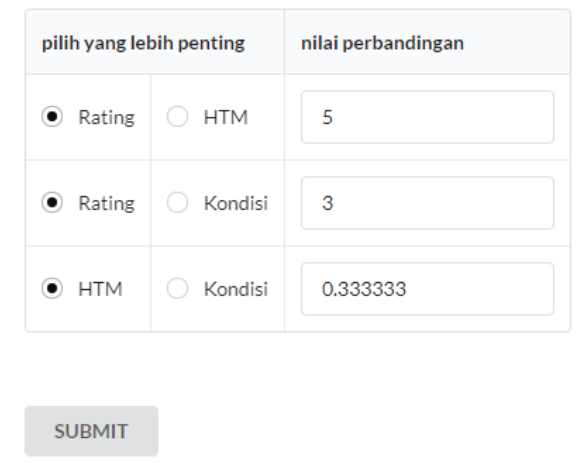

Gambar 10. Form Antarmuka Perbandingan Kriteria

Akan muncul halaman hasil perhitungan perbandingan kriteria yang berisi matriks hasil normalisasi perbandingan dari halaman pembobotan nilai kriteria dan juga sistem menampilkan perhitungan konsistensi yang telah dihitung oleh sistem. Jika consistency ratio melebihi $10 \%$ maka pengguna tidak dapat melanjutkan ke tahap selanjutnya dan akan kembali ke halaman perbandingan kriteria. Tampilan antarmuka form hasil perbandingan kriteria dapat dilihat pada gambar 11 .

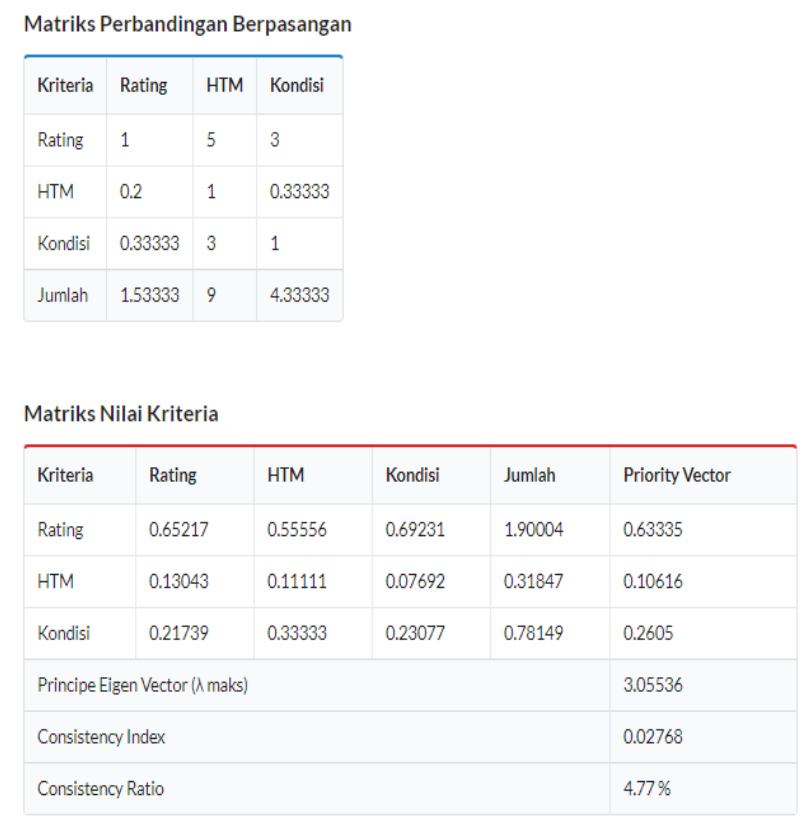

Lanjut $\rightarrow$

Gambar 11. Form Antarmuka Hasil Perbandingan Kriteria

6) Form Perbandingan Alternatif Kriteria Rating: Halaman perbandingan alternatif kriteria rating digunakan oleh pengguna dalam melakukan pembobotan nilai perbandingan berpasangan untuk kriteria rating dengan berpedoman pada tabel Saaty. Setelah pembobotan nilai selesai, maka pengguna dapat menekan tombol submit untuk melanjutkan ke tahap selanjutnya. Tampilan halaman perbandingan alternatif kriteria rating dapat ditunjukkan gambar 12 .

Perbandingan Alternatif $\rightarrow$ Rating

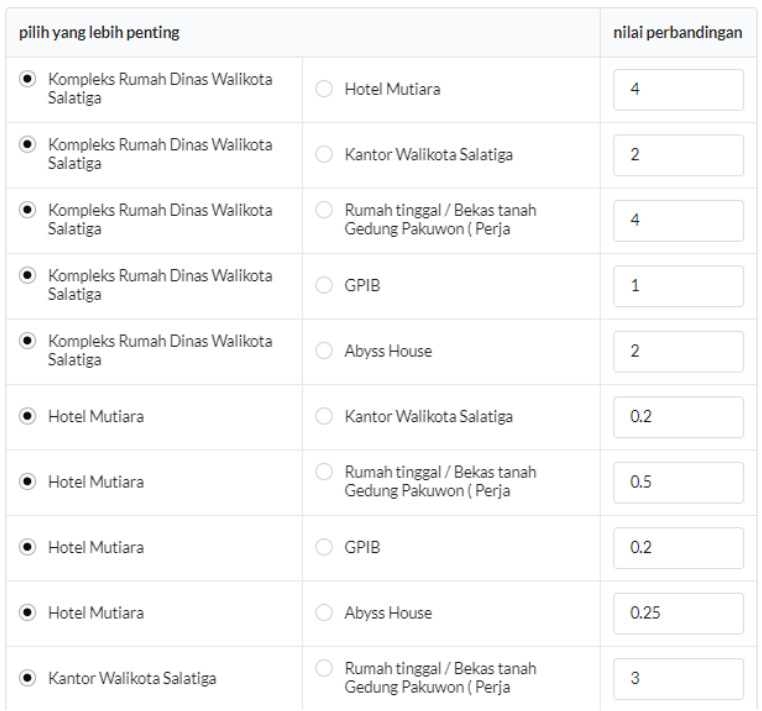

Gambar 12. Form Perbandingan Alternatif Kriteria Rating 
Halaman hasil perhitungan perbandingan kriteria rating akan muncul setelah pengguna mengisi bobot nilai kriteria rating yang berisi matriks hasil normalisasi perbandingan dari halaman pembobotan nilai kriteria rating dan juga sistem menampilkan perhitungan konsistensi yang telah dihitung oleh sistem. Jika consistency ratio melebihi $10 \%$ maka pengguna tidak dapat melanjutkan ke tahap selanjutnya dan akan kembali ke halaman perbandingan kriteria. Tampilan antarmuka form hasil perbandingan alternatif kriteria rating dapat dilihat pada gambar 13 .

\begin{tabular}{|c|c|c|c|c|c|c|c|c|}
\hline Kriteria & $\begin{array}{l}\text { Kompleks Rumah } \\
\text { Dinas Wallikota } \\
\text { Salatiga }\end{array}$ & $\begin{array}{l}\text { Hotel } \\
\text { Mutiara }\end{array}$ & $\begin{array}{l}\text { Kantor } \\
\text { Walikota } \\
\text { Salatiga }\end{array}$ & $\begin{array}{l}\text { Rumah tinggal/ Bekas } \\
\text { tanah Gedung } \\
\text { Pakuwon(Peria }\end{array}$ & GPIB & $\begin{array}{l}\text { Abyss } \\
\text { House }\end{array}$ & Jumlah & $\begin{array}{l}\text { Prioity } \\
\text { Vector }\end{array}$ \\
\hline $\begin{array}{l}\text { Kompleks Rumanh Dinas } \\
\text { Wallikota Salatiga }\end{array}$ & 0.28571 & 0.19048 & 0.23438 & 0.25806 & 0.32967 & 0.26374 & 1.56204 & 0.26034 \\
\hline Hotel Mutiara & 0.07143 & 0.04762 & 0.02344 & 0.03226 & 0.06593 & 0.03297 & 0.27364 & 0.04561 \\
\hline $\begin{array}{l}\text { Kantor Walikota } \\
\text { Salatiga }\end{array}$ & 0.14286 & 0.2381 & 0.11719 & 0.19355 & 0.08242 & 0.13187 & 0.90597 & 0.151 \\
\hline $\begin{array}{l}\text { Rumanhtingzal/Bekas } \\
\text { taran Gedung Pakwwon } \\
\text { (Peria }\end{array}$ & 0.07143 & 0.09524 & 0.03906 & 0.06452 & 0.08242 & 0.04396 & 0.39662 & 0.0661 \\
\hline GPIB & 0.28571 & 0.2381 & 0.46875 & 0.25806 & 0.32967 & 0.3956 & 1.9759 & 0.32932 \\
\hline Abyss House & 0.14286 & 0.19048 & 0.11719 & 0.19355 & 0.10989 & 0.13187 & 0.88583 & 0.14764 \\
\hline \multicolumn{8}{|c|}{ Principe Eigen Vector ( $\lambda$ maks) } & 6.30055 \\
\hline \multicolumn{8}{|l|}{ Consistency Index } & 0.06011 \\
\hline \multicolumn{8}{|l|}{ Consistency Ratio } & $4.85 \%$ \\
\hline
\end{tabular}

Gambar 13. Form Hasil Perhitungan Perbandingan Kriteria Rating

7) Form Perbandingan Alternatif Kriteria Harga Tiket Masuk: Pengguna melakukan pembobotan nilai perbandingan berpasangan untuk kriteria rating pada halaman perbandingan alternatif kriteria harga tiket masuk. Setelah pembobotan nilai alternatif telah selesai, maka pengguna dapat menekan tombol submit untuk melanjutkan ke tahap selanjutnya. Tampilan halaman perbandingan alternatif kriteria HTM dapat ditunjukkan gambar 14.

Perbandingan Alternatif $\rightarrow$ HTM

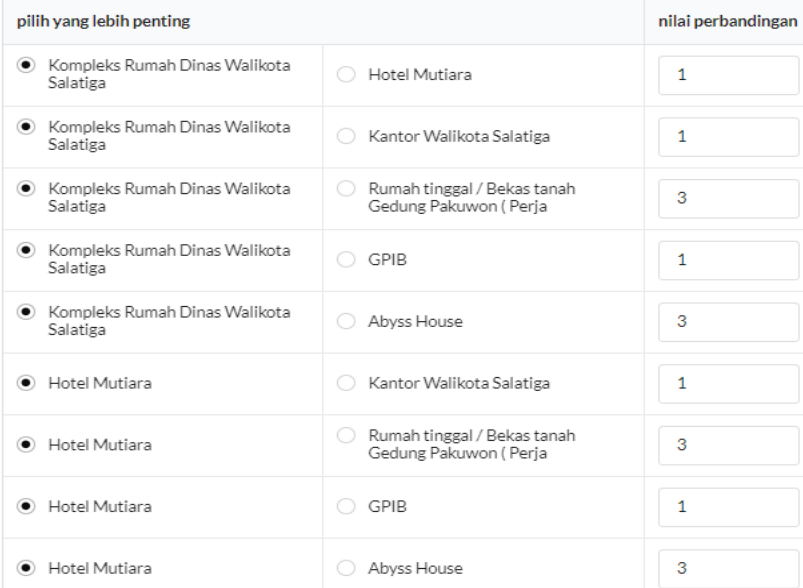

\section{Gambar 14. Form Perbandingan Alternatif Kriteria HTM}

Hasil perhitungan perbandingan berpasangan kriteria harga tiket masuk (HTM) akan muncul setelah pengguna mengisi pembobotan nilai kriteria HTM yang berisi hasil normalisasi perbandingan dari halaman pembobotan nilai kriteria HTM dan juga sistem menampilkan perhitungan konsistensi setelah pengguna mengisi bobot nilai alternatif kriteria HTM. Tampilan hasil perbandingan alternatif kriteria HTM dapat dilihat pada gambar 15.

Matriks Nilai Kriteria

\begin{tabular}{|c|c|c|c|c|c|c|c|c|}
\hline Kriteria & $\begin{array}{l}\text { Kompleks Rumah } \\
\text { Dinas Walikota } \\
\text { Salatiga }\end{array}$ & $\begin{array}{l}\text { Hotel } \\
\text { Mutiara }\end{array}$ & $\begin{array}{l}\text { Kantor } \\
\text { Walikota } \\
\text { Salatiga }\end{array}$ & $\begin{array}{l}\text { Rumah tinggal/ Bekas } \\
\text { tanah Gedung Pakuwon( } \\
\text { Perja }\end{array}$ & GPIB & $\begin{array}{l}\text { Abyss } \\
\text { House }\end{array}$ & Jumlah & $\begin{array}{l}\text { Priority } \\
\text { Vector }\end{array}$ \\
\hline $\begin{array}{l}\text { Kompleks Rumah Dinas } \\
\text { Walikotas Salatiga }\end{array}$ & 0.21429 & 0.21429 & 0.21429 & 0.21429 & 0.21429 & 0.21429 & 1.28571 & 0.21429 \\
\hline Hotel|Mutiara & 0.21429 & 0.21429 & 0.21429 & 0.21429 & 0.21429 & 0.21429 & 1.28571 & 0.21429 \\
\hline Kantor Waliksta Salatiza & 0.21429 & 0.21429 & 0.21429 & 0.21429 & 0.21429 & 0.21429 & 1.28571 & 0.21429 \\
\hline $\begin{array}{l}\text { Rumah tinggal / Pekas } \\
\text { tanah Gedung Pakuwon( } \\
\text { Perja }\end{array}$ & 0.07143 & 0.07143 & 0.07143 & 0.07143 & 0.07143 & 0.07143 & 0.42857 & 0.07143 \\
\hline GPIB & 0.21429 & 0.21429 & 0.21429 & 0.21429 & 0.21429 & 0.21429 & 1.28571 & 0.21429 \\
\hline Abyss House & 0.07143 & 0.07143 & 0.07143 & 0.07143 & 0.07143 & 0.07143 & 0.42857 & 0.07143 \\
\hline \multicolumn{8}{|c|}{ Principe Elgen Vector ( $\lambda$ maks) } & 6 \\
\hline \multicolumn{8}{|l|}{ Consistency Index } & 0 \\
\hline \multicolumn{8}{|l|}{ Consistency Ratio } & $0 \%$ \\
\hline
\end{tabular}

Gambar 15. Form Hasil Perbandingan Alternatif Kriteria HTM

8) Form Perbandingan Alternatif Kriteria Kondisi: Pengguna melakukan pembobotan nilai perbandingan berpasangan terhadap alternatif untuk kriteria kondisi pada form ini. Setelah pembobotan nilai alternatif kriteria kondisi selesai dilakukan, maka pengguna dapat menekan tombol submit untuk melihat hasil perhitungan pembobotan nilai. Tampilan antarmuka form perbandingan alternatif kriteria kondisi ditunjukkan pada gambar 16.

Perbandingan Alternatif $\rightarrow$ Kondisi
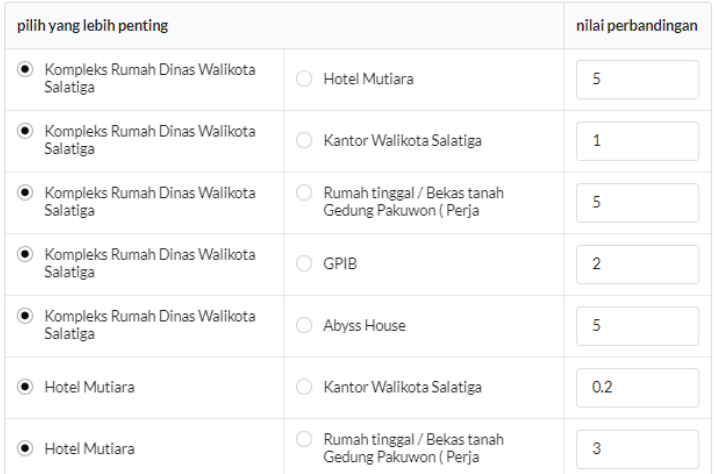

Gambar 16. Form Hasil Perbandingan Alternatif Kriteria Kondisi

Halaman hasil normalisasi dan pengetesan konsistensi perbandingan alternatif kondisi akan muncul setelah pengguna mengisi bobot nilai alternatif kriteria harga tiket masuk (HTM). Sistem menampilkan perhitungan 
konsistensi setelah pengguna mengisi bobot nilai alternatif kriteria kondisi. Tampilan hasil perbandingan alternatif kriteria kondisi ditunjukkan gambar 17.

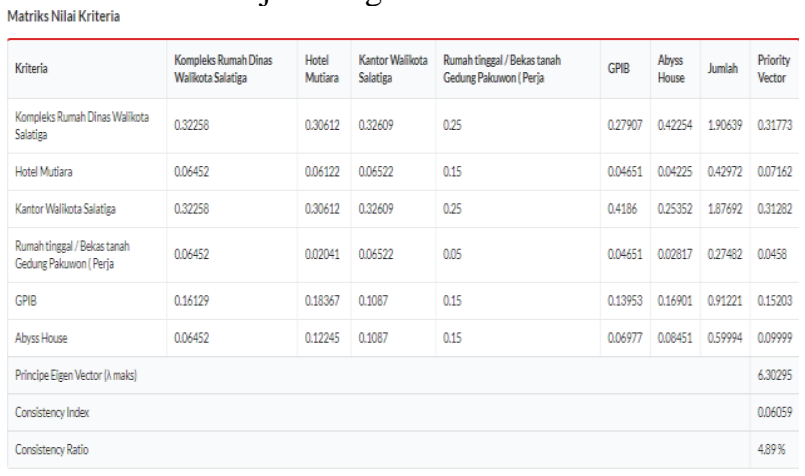

Gambar 17. Form Hasil Perbandingan Alternatif Kriteria Kondisi

9) Form Nilai Akhir: Pengguna akan menuju ke halaman hasil perhitungan yang menampilkan hasil akhir dari menu hitung AHP etelah melakukan pembobotan nilai semua kriteria dan alternatif. Halaman hasil perhitungan menampilkan priority vector dari tiap alternatif dan tiap kriteria, dan juga menampilkan rekomendasi cagar budaya menurut perhitungan niilai akhir. Halaman nilai akhir ditunjukkan gambar 18.
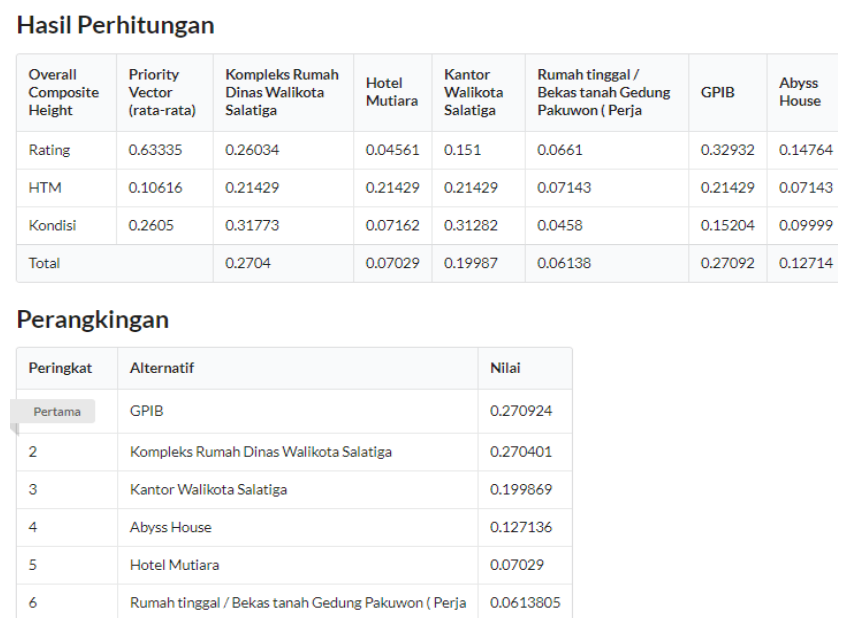

\section{Gambar 18. Form Nilai Akhir Hitung AHP}

\section{Hasil Pengujian Terhadap Sistem}

Dalam mengetahui apakah sistem berjalan sesuai dengan alur yang telah dibuat dan agar tidak ada issue atau bug di dalam sistem, maka dilakukan pengetesan terhadap sistem. Akan dilakukan pengujian pada fungsi pencarian cagar budaya menggunakan web-GIS, daftar cagar budaya dan hitung AHP.

Tujuan dari pengujian pada fitur pencarian cagar budaya digunakan untuk mengetahui apakah informasi cagar budaya dan titik lokasi yang ditampilkan sesuai dengan yang dicari oleh pengguna. Hasil pengujian pada fitur webGIS dapat dilihat pada Tabel XVII.
TABEL XVII

TABEL PENGUJIAN FUNGSI WEB-GIS

\begin{tabular}{|l|l|l|}
\hline \multicolumn{1}{|c|}{ Test Case } & \multicolumn{1}{c|}{$\begin{array}{c}\text { Hasil yang } \\
\text { Diharapkan }\end{array}$} & \multicolumn{1}{c|}{ Hasil Pengujian } \\
\hline $\begin{array}{l}\text { Pengguna } \\
\text { melakukan } \\
\text { fungsi } \\
\text { pencarian. }\end{array}$ & $\begin{array}{l}\text { Sistem } \\
\text { menampilkan } \\
\text { informasi mengenai } \\
\text { cagar budaya sesuai } \\
\text { dengan kata kunci. }\end{array}$ & $\begin{array}{l}\text { Sistem } \\
\text { menampilkan } \\
\text { informasi mengenai } \\
\text { cagar budaya sesuai } \\
\text { dengan kata kunci. }\end{array}$ \\
\hline $\begin{array}{l}\text { Pengujian } \\
\text { keakuratan } \\
\text { marker pada } \\
\text { peta }\end{array}$ & $\begin{array}{l}\text { Saat marker di-klik } \\
\text { maka akan } \\
\text { memunculkan } \\
\text { informasi mengenai } \\
\text { cagar budaya } \\
\text { tersebut }\end{array}$ & $\begin{array}{l}\text { Saat marker di-klik } \\
\text { maka memunculkan } \\
\text { informasi mengenai } \\
\text { cagar budaya } \\
\text { tersebut }\end{array}$ \\
\hline $\begin{array}{l}\text { Pengetesan } \\
\text { keakuratan } \\
\text { marker pada } \\
\text { peta }\end{array}$ & $\begin{array}{l}\text { Seharusnya letak } \\
\text { cagar budaya pada } \\
\text { peta sesuai dengan } \\
\text { kondisi asli }\end{array}$ & $\begin{array}{l}\text { Letak cagar budaya } \\
\text { pada kondisi asli } \\
\text { sesuai dengan peta }\end{array}$ \\
\hline
\end{tabular}

Pengujian selanjutnya dilakukan pada fungsi daftar cagar budaya agar dapat mengetahui apakah fungsi daftar cagar budaya yang dirancang telah sesuai menampilkan informasi yang diharapkan dan berjalan tanpa issue. Tabel pengujian fungsi daftar cagar budaya ditunjukkan Tabel XVIII.

TABEL XVIII

TABEL PENGUJIAN FUNGSI DAFTAR CAGAR BUdAYA

\begin{tabular}{|l|l|l|}
\hline \multicolumn{1}{|c|}{ Test Case } & \multicolumn{1}{|c|}{$\begin{array}{c}\text { Hasil yang } \\
\text { Diharapkan }\end{array}$} & Hasil Pengujian \\
\hline $\begin{array}{l}\text { Pengguna } \\
\text { mengklik } \\
\text { cagar budaya }\end{array}$ & $\begin{array}{l}\text { Sistem akan } \\
\text { menampilkan } \\
\text { informasi cagar } \\
\text { budaya. }\end{array}$ & $\begin{array}{l}\text { Sistem } \\
\text { menampilkan } \\
\text { informasi cagar } \\
\text { budaya. }\end{array}$ \\
\hline $\begin{array}{l}\text { Admin } \\
\text { menambahkan } \\
\text { data cagar } \\
\text { budaya. }\end{array}$ & $\begin{array}{l}\text { Data cagar budaya } \\
\text { baru akan muncul di } \\
\text { daftar cagar budaya }\end{array}$ & $\begin{array}{l}\text { Data cagar budaya } \\
\text { muncul di daftar } \\
\text { cagar budaya. }\end{array}$ \\
\hline
\end{tabular}

Agar dapat mengetahui fungsi-fungsi yang berada pada menu hitung AHP berjalan sesuai yang diharapkan dan hasil perhitungan AHP oleh sistem akurat jika dibandingkan dengan perhitungan AHP secara manual, maka dilakukan pengujian terhadap menu hitung AHP. Tabel pengujian menu hitung AHP ditunjukkan pada Tabel XIX.

TABEL XIX

Tabel Pengujian Menu Hitung AHP

\begin{tabular}{|l|l|l|}
\hline \multicolumn{1}{|c|}{ Test Case } & \multicolumn{1}{|c|}{$\begin{array}{c}\text { Hasil yang } \\
\text { Diharapkan }\end{array}$} & Hasil Pengujian \\
\hline $\begin{array}{l}\text { Admin mengelola } \\
\text { data kriteria } \\
\text { (tambah, } \text { edit dan } \\
\text { delete) }\end{array}$ & $\begin{array}{l}\text { Sistem akan } \\
\text { mencatat } \\
\text { perubahan pada } \\
\text { data kriteria. }\end{array}$ & $\begin{array}{l}\text { Sistem mencatat } \\
\text { perubahan pada } \\
\text { kriteria }\end{array}$ \\
\hline $\begin{array}{l}\text { Admin mengelola } \\
\text { data alternatif } \\
\text { (tambah, } \text { edit dan } \\
\text { delete) }\end{array}$ & $\begin{array}{l}\text { Sistem akan } \\
\text { mencatat } \\
\text { perubahan pada } \\
\text { data alternatif. }\end{array}$ & $\begin{array}{l}\text { Sistem mencatat } \\
\text { perubahan pada } \\
\text { alternatif. }\end{array}$ \\
\hline
\end{tabular}




\begin{tabular}{|c|c|c|}
\hline Test Case & $\begin{array}{c}\text { Hasil yang } \\
\text { Diharapkan }\end{array}$ & Hasil Pengujian \\
\hline $\begin{array}{l}\text { Pengguna } \\
\text { melakukan } \\
\text { pembobotan nilai } \\
\text { menggunakan } \\
\text { nilai yang tidak } \\
\text { konsisten. }\end{array}$ & $\begin{array}{l}\text { Sistem akan } \\
\text { memunculkan } \\
\text { peringatan bahwa } \\
\text { nilai yang } \\
\text { dilakukan } \\
\text { pembobotan nilai } \\
\text { tidak konsisten. }\end{array}$ & $\begin{array}{l}\text { Sistem } \\
\text { memunculkan } \\
\text { peringatan bahwa } \\
\text { nilai dilakukan } \\
\text { pembobotan nilai } \\
\text { tidak konsisten. }\end{array}$ \\
\hline $\begin{array}{l}\text { Pengguna tidak } \\
\text { mengisi beberapa } \\
\text { kolom } \\
\text { pembobotan nilai. }\end{array}$ & $\begin{array}{l}\text { Sistem akan } \\
\text { memunculkan } \\
\text { peringatan bahwa } \\
\text { nilai tidak boleh } \\
\text { ada yang kosong. }\end{array}$ & $\begin{array}{l}\text { Sistem } \\
\text { memunculkan } \\
\text { peringatan nilai } \\
\text { tidak boleh } \\
\text { kosong. } \\
\end{array}$ \\
\hline $\begin{array}{l}\text { Pengguna mengisi } \\
\text { pembobotan nilai } \\
\text { sesuai dengan } \\
\text { format kemudian } \\
\text { menekan tombol } \\
\text { submit. }\end{array}$ & $\begin{array}{l}\text { Sistem akan } \\
\text { menampilkan } \\
\text { halaman hasil } \\
\text { penilaian dengan } \\
\text { perhitungan } \\
\text { sesuai rumus } \\
\text { AHP. }\end{array}$ & $\begin{array}{l}\text { Sistem } \\
\text { menampilkan } \\
\text { halaman hasil } \\
\text { penilaian dengan } \\
\text { perhitungan } \\
\text { sesuai rumus } \\
\text { AHP. }\end{array}$ \\
\hline
\end{tabular}

\section{KESIMPULAN DAN SARAN}

\section{A. Kesimpulan}

Dalam dibangunnya sistem informasi geografis rekomendasi cagar budaya ini, dapat memberikan solusi untuk mencari cagar budaya yang berada di Kota Salatiga. Diterapkannya metode analytical hierarchy process (AHP) pada SIG rekomendasi cagar budaya ini agar pengguna yang akan memilih calon cagar budaya yang akan dikunjungi menjadi lebih yakin. Hasil perhitungan AHP yang dilakukan secara manual dibandingkan dengan perhitungan pada sistem juga ditemukan menghasilkan hasil yang akurat. Berdasarkan hasil pengujian sistem, ditemukan semua fungsi sistem telah memberikan informasi yang sesuai dan berjalan dengan baik.

\section{B. Saran}

Berikut ini saran dalam pembangunan sistem informasi rekomendasi cagar budaya kedepannya. SIG rekomendasi cagar budaya ini hanya diperuntukkan untuk Kota Salatiga, diharapkan pada pengembangan sistem informasi dapat dikembangkan untuk tingkat selanjutnya seperti provinsi.
Sebaiknya ada hubungan komunikasi antar pengguna dalam sistem informasi ini dalam bentuk komentar mengenai cagar budaya yang akan dikunjungi.

\section{DAFTAR PUSTAKA}

[1] S. Rahardjo, Sejarah Bangunan Cagar Budaya Kota Salatiga, Salatiga: Pemerintah Daerah Kota Salatiga, 2013.

[2] N. Ketut, P. Gayatri, D. P. Githa \& I. P. A. Dharmaadi, "Sistem Informasi Geografis Rekomendasi Objek Wisata Bali Menggunakan Metode TOPSIS," Merpati., vol. 6, no. 2, pp. 96107, 2018.

[3] D. Rahardjo, A. P. Peta, "Prototipe Sistem Informasi Geografis Fasilitas Kesehatan di Kota Cirebon Berbasis Web," Jurnal Teknik Informatika Dan Sistem Informasi, vol. 1,no. 3, pp. 210220, 2015.

[4] T.L. Saaty, The Analytical Hierarchy Process, New York: McGraw Hill, 1980.

[5] M. Kaneko., "Sistem Informasi Toko X Menggunakan Metode Analytical Hierarchy Process Untuk Rekomendasi Supplier," Jurnal Teknik Informatika Dan Sistem Informasi., vol. 3,no. 2, pp. 269-280, 2017.

[6] R. S. Hamdhani, R. V. Imbar, "Sistem Informasi Pemilihan Mobil Bekas Menggunakan Decision Support System Analytical Hierarchy Process pada Showroom Yokima Motor Bandung," Jurnal Teknik Informatika Dan Sistem Informasi., vol. 1, no. 2, pp. 88-101, 2015.

[7] E. Prahasta, Sistem Informasi Geografis (Konsep- Konsep Dasar Perspektif Geodesi dan Geomatika), Bandung: Informatika, 2014.

[8] T. Sutabri, Konsep sistem informasi. Penerbit Andi, 2012.

[9] A. Lieberty, R. V Imbar, "Sistem Informasi Meramalkan Penjualan Barang Dengan Metode Double Exponential Smoothing (Studi kasus: PD. Padalarang Jaya)," Jurnal Teknik Informatika Dan Sistem Informasi., vol. 1, no. 1, pp. 27-32, 2015.

[10] R. A. Sukamto, M. Shalahuddin, Rekayasa Perangkat Lunak Terstruktur Dan Berorientasi Objek, Bandung: Informatika, 2013.

[11] "Analisis Pembentukan Class Diagram dengan menggunakan metode Domain Modelling," 2014. [Online]. Tersedia: https://socs.binus.ac.id/2014/03/19/analisis-pembentukan-classdiagram-dengan-menggunakan-metode-domain-modelling/.

[12] Kusrini, Konsep dan Aplikasi Sistem Pendukung Keputusan, Yogyakarta: Andi, 2007.

[13] A. Dhammahito, A. Herlambang \& J. Kasih, "Event Cosplay Organizer Online dengan Sistem Rekomendasi Juri

Menggunakan Perbandingan Metode AHP dan SAW ( Studi Kasus pada Kaze Production )," Jurnal Teknik Informatika Dan Sistem Informasi., vol. 5, no.2, pp. 256-266, 2019.

[14] A. Kristanto, Perancangan Sistem Informasi dan Aplikasinya, Revisi I,. Yogyakarta: Gava Media, 2018.

[15] Kementerian Pendidikan dan Kebudayaan Republik Indonesia, "Sistem Registrasi Nasional Cagar Budaya." [Online]. Tersedia: https://cagarbudaya.kemdikbud.go.id/public/objek/index/2/bangu nan. 